\title{
Using the geological record to assess the changing status of Danish lakes
}

\author{
Emily G. Bradshaw and Peter Rasmussen
}

The Danish Nationwide Aquatic Monitoring Programme (Kristensen et al. 1991; Kronvang et al. 1996) is one of the most comprehensive in Europe and, compared with other national programmes, was put in place at an early date: the systematic monitoring of freshwater lakes began in 1989. As with all such programmes of long-term environmental monitoring, its value multiplies with time as an increasing number of scientific hypotheses can be tested and management questions addressed using the growing body of data. However, the aquatic monitoring data, as for many natural systems, are limited to the scale of decades and so may not identify important longer-term trends or be useful in the determination of 'baseline' (pre-industrial or pre-agricultural impact) conditions.

The study of lake sediments, palaeolimnology, offers a means of extending the monitoring of lake status back in time and can be used to determine baseline conditions (e.g. for water chemistry variables), to define trends and rates of change, and to identify the causes of change (Battarbee 1999). The data obtained from palaeolimnological studies can provide a yardstick against which current and future changes may be assessed. Furthermore, restoration targets for lakes impacted by for example enhanced nutrient loading, will be aided by a knowledge of the environmental conditions of a pre-disturbance state, defining both potential targets for restoration and the limits to what a restoration project might achieve (Battarbee 1999).

\section{Application of palaeolimnology to the EU's Water Framework Directive}

Palaeoecology has been a core area of research at the Geological Survey of Denmark and Greenland (GEUS), going back to the earliest days of the Geological Survey of Denmark (Rasmussen 1988). This long tradition has been followed and developed by successive research teams with new skills and techniques being taken on board. For example, advances in numerical techniques in the 1980s led to the development of transfer function methods for estimating past water chemistry variables from the microfossil record (Birks et al. 1990). Over the last 13 years, a transfer function to estimate past in-lake nutrient (Total Phosphorus, TP) concentrations for Danish lakes from sedimentary diatom assem- blages has been created, developed and applied in many studies (e.g. Anderson \& Odgaard 1994; Bennion et al. 1996; Bradshaw 2001; Bradshaw et al. 2002).

The wealth of palaeolimnological data on numerous freshwater and brackish lakes in Denmark, accumulated over many years, provides a crucial resource relevant to the implementation of the European Union's Water Framework Directive. This Directive, from 2000, aims to achieve a 'good' ecological status for all EU water bodies by the year 2015 . One of the key considerations of the Water Framework Directive is the determination of baseline conditions, or 'reference status', the yardstick against which contemporary water quality status can be assessed and future targets can be realistically defined. The reference status need not, of course, be a stable condition, nor will the unimpacted status be the same for different lakes in different landscapes (Søndergaard et al. 2003).

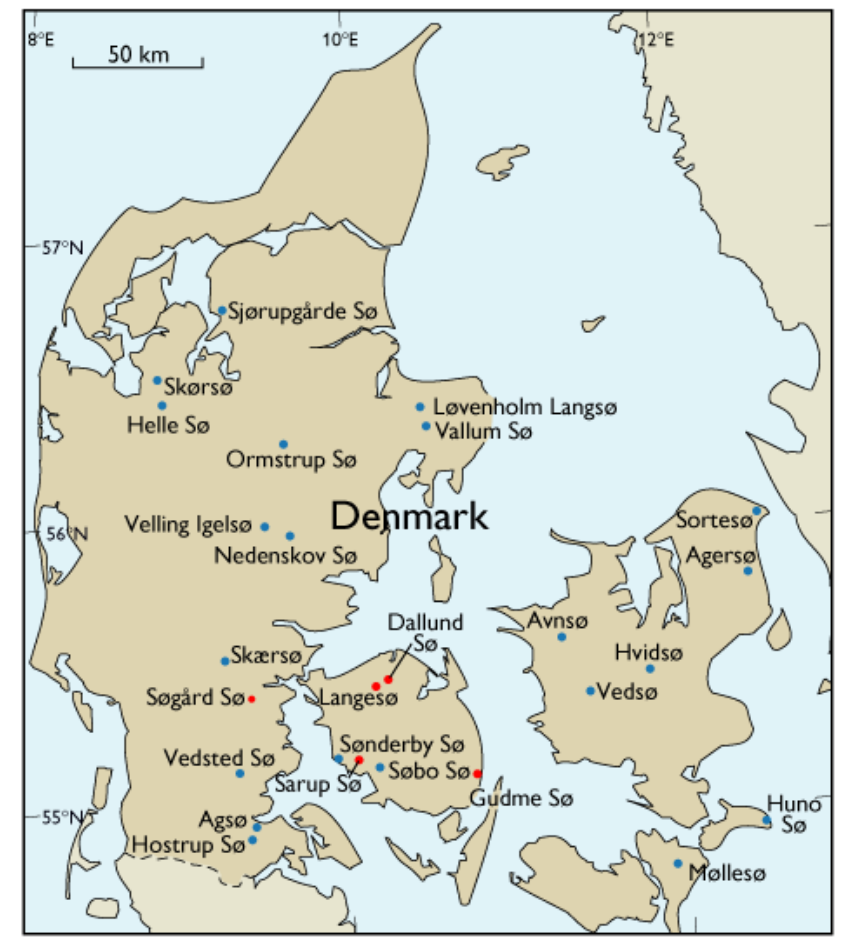

Fig. 1. Map of Denmark with the 21 lakes (blue dots) included in additional palaeolimnological analyses made for the European Union's Water Framework Directive report (Amsinck et al. 2003) and other lakes (red dots) mentioned in the text. 
Two recent reports (Amsinck et al. 2003; Søndergaard et al. 2003) that are the result of collaboration between the National Environmental Research Institute (NERI), the Danish Forest and Nature Agency, the Danish counties and the Survey, set the foundations for implementation of the EU's Water Framework Directive for Danish lakes. The archive of palaeolimnological data collated by the Survey over many years, and complemented by parallel studies at NERI, proved an invaluable basis for the consideration of reference status for Danish lakes. In addition, new analyses (diatoms, GEUS; cladocerans, NERI) were made for 21 lakes (Fig. 1) for four time-slices: 1850, 1900, 1950 and 2000. This study was made possible, on a very limited budget, due to the wellkept archive of lake sediments held by GEUS: lake sediment cores that had been sampled and dated for a previous pollenbased study (Nielsen 2003) were made available for additional analyses.

\section{Lake eutrophication - a long-term view}

In addition to the Survey's long tradition of pollen analysis, many lake sediment-based studies have utilised the tech- niques of diatom and plant macrofossil analyses. The example given here (Fig. 2) shows data from Søgård Sø. On the basis of the macrofossil data for aquatic plants, the record has been divided into three stages. The lower section of the sediment core (c. 200 to $147 \mathrm{~cm}$ ) records sparse remains of submerged macrophytes, but a relatively well-developed community of floating-leaved plants (e.g. Nymphaea: waterlily). In this earlier part of the record, the diatom assemblage reflects high total phosphorus concentrations in the lake. The second stage $(c .147$ to $78 \mathrm{~cm})$ shows a much expanded vegetation of submerged aquatic macrophytes (e.g. Stratiotes aloides: water-soldier; Nitella and Chara: stoneworts; Potamogeton: pondweed). Egg-cocoons of the leech Piscicola geometra also indicate the presence of submerged macrophytes at this time (Odgaard \& Rasmussen 2001). The third stage $(c .78$ to $0 \mathrm{~cm})$ sees a greatly reduced number of plant macrofossil remains and P. geometra cocoons in the sediment, coinciding with a major increase in the diatom-inferred TP concentration.

The record from Søgard Sø demonstrates the pattern of eutrophication seen in many Danish lakes during the last century. Before 1940 the lake had a rich aquatic macrophyte vegetation, but with increased nutrient concentrations in the 1940 s and later, this macrophyte cover disappeared. This example is from just one of many Danish lakes that have been the subject of palaeolimnological studies.

Figure 3 summarises some of the results from the study of 21 Danish lakes carried out in connection with the Water Framework Directive report (Amsinck et al. 2003). The results of the analysis of sedimentary diatom remains suggest that many of the lakes underwent eutrophication during the past 150 years, but that in-lake nutrient concentrations were already surprisingly high for many sites in 1850 . This conclusion is supported by the few studies of longer lake sediment sequences for Danish lakes, e.g. Langesø (Anderson \& Odgaard 1994), Dallund Sø (Bradshaw 2001), Gudme Sø and Sarup Sø (unpublished data, P. Rasmussen and E.G. Bradshaw) that demonstrate that some lakes have been impacted by human activities over the scale of centuries and millennia. Thus,

Fig. 2. Summary stratigraphic data for Søgaard Sø (unpublished data, P. Rasmussen and defining a true baseline condition for many lakes N.J. Anderson). 
requires the consideration of long time periods, only obtainable by use of the geological record.

\section{Environmental management requires both foresight and geological perspectives}

The study of palaeolimnological records has much to contribute to lake management questions and problems. As well as determining when and to what extent Danish lakes were influenced by human activities, sites may be identified that have experienced relatively little impact over time and thus may be of greater conservation value (again, providing the yardstick against which to judge contemporary systems). Also, rates of change can be informative with respect to the resistance of ecosystems to forcing events and the likelihood of future stability.

Pressing environmental problems and management questions, for example those posed by the EU Water Framework Directive, must draw on knowledge and experience gained over many years. The Danish Nationwide Aquatic Monitoring Programme has provided a rich resource to draw on when addressing the requirements of this Directive, putting Denmark in a stronger position than many other European countries. The long tradition of environmental history research in Denmark, at the Survey in particular, has likewise provided a strong base of knowledge, the fruits of which continue to be harvested, as illustrated by the response to the demands of the Water Framework Directive.

The management questions and the demands of the Danish society in the future may not be predictable today (e.g. problems relating to climate change). Therefore, the importance of maintaining relevant and well-established monitoring programmes for natural systems cannot be overstated (see also Sand-Jensen 1997; Wolf 2003). Their continuation, however, requires foresight and a belief in investment for the future. Another illustration of this comes from the area of forest history research. Since 1948, Survey scientists have monitored natural forest development in Denmark, one of the longest surveys of its kind in Europe. The experience and knowledge gained has been of vital importance for the understanding of natural forest processes and for nature conservation in Danish forests.

Once interrupted or discontinued, the value of a monitoring programme diminishes greatly. In the same way, research expertise developed over many years is a valuable resource that grows over time to become more than the sum of a research group's parts. Without the foresight to support and continue relevant and successful programmes, the knowledge-base that has been built up can rapidly disintegrate, but the effects of this may only be fully appreciated in subsequent decades (see e.g. Sand-Jensen 1995).

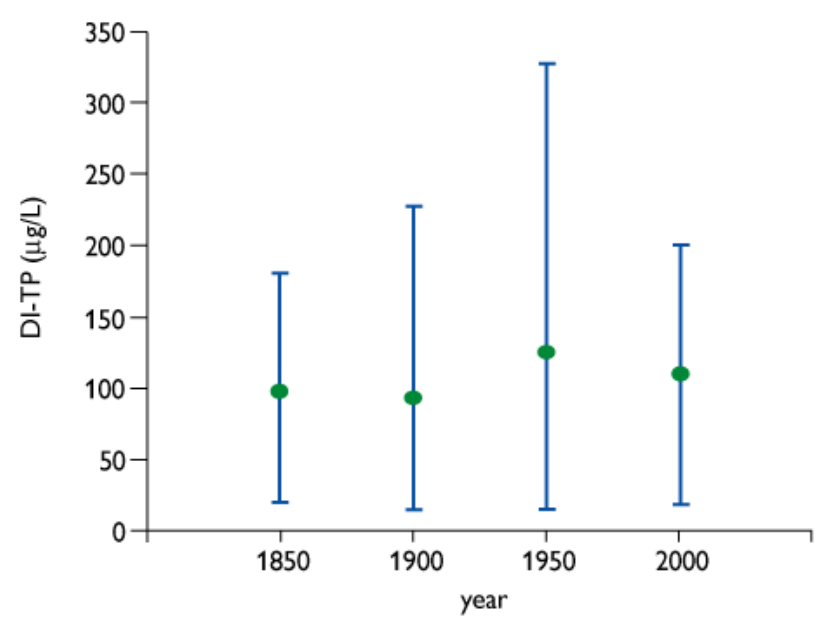

Fig. 3. Mean diatom-inferred total phosphorus values (DI-TP) for the additional sites studied for the Water Framework Directive. Maximum and minimum values are shown as 'error' bars. (Note: N=17; the estimation of TP concentrations was not possible for all sites, some being outside the range of the transfer function model.)

Of human history, Anne Knudsen, chief editor of the national Danish newspaper Weekendavisen, has incisively stated that: "Lacking knowledge of history leaves us vulnerable and wide open to cock-and-bull stories and demagogy". The same can also certainly be said for environmental history. For example, based on limited information, it is a commonly held belief that the pollution of Danish lakes is a relatively modern phenomenon, associated with post-industrial population growth and agricultural development. The study of environmental history shows us that this is a misconception.

\section{References}

Amsinck, S.L. et al. 2003: Vandrammedirektivet og danske søer. Del 2: Palæoøkologiske undersøgelser. Faglig rapport fra Danmarks Miljøundersøgelser 476, $120 \mathrm{pp}$.

Anderson, N.J. \& Odgaard, B.V. 1994: Recent palaeolimnology of three shallow Danish lakes. Hydrobiologia 256-257, 411-422.

Battarbee, R.W. 1999: The importance of palaeolimnology to lake restoration. Hydrobiologia 395-396, 149-159.

Bennion H., Juggins S. \& Anderson, N.J. 1996: Predicting epilimnetic phosphorus concentrations using an improved diatom-based transfer function and its application to lake eutrophication management. Environmental Science and Technology 30, 2004-2007.

Birks, H.J.B., Line, M., Juggins, S., Stevenson, A.C. \& ter Braak, C.J.F. 1990: Diatoms and $\mathrm{pH}$ reconstruction. Philosophical Transactions of the Royal Society of London, Series B - Biological Sciences 327, 263-278.

Bradshaw, E.G. 2001: Linking land and lake. The response of lake nutrient regimes and diatoms to long-term land-use change in Denmark, 118 pp. Unpublished Ph.D. thesis, University of Copenhagen, Denmark

Bradshaw, E.G., Anderson, N.J., Jensen, J.P. \& Jeppesen, E. 2002: Phosphorus dynamics in Danish lakes and the implications for diatom ecology and palaeoecology. Freshwater Biology 47, 1963-1975. 
Kristensen, P., Jensen, J.P., Jeppesen, E. \& Erlandsen, M. 1991: Ferske vandområder - søer. Vandmiljøplanens Overvågningsprogram 1990. Faglig rapport fra Danmarks Miljøundersøgelser 38, 104 pp.

Kronvang, B, Svendsen, L.M., Larsen, S.E. \& Jensen, J.P. 1996: Monitoring and modelling of nutrient loads in Danish streams and lakes. In: Riverine input to coastal areas - notes from a workshop on methodology, Tema Nord 1996: 529, 53-60. Copenhagen: Nordic Council of Ministers

Nielsen, A.B. 2003: Pollen based quantitative estimation of land cover. Relationships between pollen sedimentation in lakes and land cover as seen on historical maps in Denmark AD 1800, 135 pp. Unpublished Ph.D. thesis, University of Copenhagen, Denmark.

Odgaard, B.V. \& Rasmussen, P. 2001: The occurrence of egg-cocoons of the leech Piscicola geometra (L.) in recent lake sediments and their relationship with remains of submerged macrophytes. Archiv für Hydrobiologie 152 (4), 671-686.
Rasmussen, L.B. 1988: En jordisk krønike. Træk af DGU's historie 1888-1988, 114 pp. København: Danmarks Geologiske Undersøgelse, Miljøministeriet.

Sand-Jensen, K. 1995: Furesøen gennem 100 år. Naturens Verden 5, 176-187.

Sand-Jensen, K. 1997: Eutrophication and plant communities in Lake Fure during 100 years. In: Sand-Jensen, K. \& Pedersen, O. (eds) Freshwater Biology. Priorities and development in Danish research, 26-38. Copenhagen: Gad.

Søndergaard, M., Jeppesen, E., Jensen, J.P., Bradshaw, E., Skovgaard, H. \& Grünfeld, S. 2003: Vandrammedirektivet og danske søer. Del 1: Søtyper, referencetilstand og økologiske kvalitetsklasser. Faglig rapport fra Danmarks Miljøundersøgelser 475, 142 pp.

Wolf, A. 2003: Tree dynamics in Draved Forest. A long-term study of a temperate deciduous forest in Denmark, 164 pp. Unpublished Ph.D. thesis, The Royal Veterinary and Agricultural University, Copenhagen, Denmark.

\section{Authors' address}

Geological Survey of Denmark and Greenland, Øster Voldgade 10, DK-1350 Copenhagen K, Denmark. E-mail: egb@geus.dk 